\title{
Et land i krig (II)
}

\section{Tonny Brems Knudsen}

Bogens fundamentale lære er ikke, at det militære instrument skal lægges på hylden, men at grundlaget skal være i orden og i overensstemmelse med basale internationale principper

Lars Halskov og Jacob Svendsen: Et land i krig. Hvordan Danmark blev krigsførende - og politikere og generaler famlede i blinde. København, Politikens Forlag, 2012. 703 sider.

Det erklærede formål med Et land $i$ krig er at "fortælle den store historie om Danmark i krig", samt at give svar på, hvordan det gik til, at Danmark "gik fra at være optaget af humanitære opgaver og FN-missioner til at være i front i offensive krige" (s. 7). Den målsætning lever bogen også op til. Læseren får den store historie om dansk krigsdeltagelse i perioden 2001 til 2011 med fokus på 'krigen mod terror' og krigene i Afghanistan og Irak samt afslutningsvis den humanitære intervention i Libyen i 2011.

Som forfatterne selv skriver i forordet, er der tale om en journalistisk bog, og det har selvfølgelig nogle konsekvenser. Den videnskabelige genres løbende og præcise kildehenvisninger er fraværende, og forfatterne bliver til tider fanget mellem ønsket om at lægge tingene objektivt og nøgternt frem og ønsket om at afdække skyggesiden af Danmarks militære engagement (s. 8), herunder fejltagelser der kan henføres til Danmarks i udgangspunktet begrænsede erfaringer som krigsførende land.

Til gengæld er bogen med dens vekslende skildringer af centrale internationale begivenheder, vanskelige politiske og militære beslutninger, og personlige beretninger og omkostninger afgjort spændende læsning. Man får en alsidig, men sammenhængende fortælling om dansk krigsdeltagelse i denne periode, man får et godt indtryk af de dilemmaer, som de politiske og militære beslutningstagere på højere og lavere niveauer har stået overfor, og man kommer ofte meget tæt på både beslutninger og kamphandlinger. 


\section{LITTERATUR}

Selvom der er oplysninger og beretninger, der er nye for offentligheden - $\mathrm{fx}$ overvejelserne om at stille med flere hundrede kampsoldater til invasionen af Irak (s.168-171) er det meste kendt stof, dvs. begivenheder, oplysninger og overvejelser, der har været fremme før. Men der er tale om vigtige emner og spørgsmål, som fortjener yderligere offentlig debat såvel som politisk eftertænksomhed. Det er det bogen lægger op til, og det er det bogen inviterer til, dels fordi det er dens ærinde, dels fordi også dens egne fremstillinger og budskaber naturligt nok kan diskuteres. Det gælder også for de tre emner, som tages op nedenfor, nemlig vurderingen af Danmarks militære aktivisme over tid, den danske deltagelse i den kontroversielle Irak-krig, og dansk udenrigspolitik efter den humanitære intervention i Libyen.

\section{Danmarks militære aktivisme}

Bogens fortjeneste er blandt andet, at den afdækker krigens militære og politiske dilemmaer samt de menneskelige omkostninger. Man får også fornemmelsen af, hvor let man kan komme galt af sted, når man vælger de militære midler. Her er bogens samlede budskab, trods dens polemiske undertitel og flere kritiske afsnit, ikke først og fremmest, at lige netop Danmark er kommet galt af sted, men snarere at meget kan og vil gå galt, når man kaster sig ud $\mathrm{i}$ militær magtanvendelse. Det viser bogens afdækning af, hvordan gode planer har lidt skibsbrud for de koalitioner som helhed, som Danmark har været en del af i Afghanistan og Irak. Der er også sympati og respekt i beskrivelserne af, hvordan danske soldater har udholdt voldsomt pres og smertelige tab i fx forsvaret af Musa Qala i Afghanistan (kapitel 10) - et forsvar som angiveligt gjorde et dybt indtryk på beslutningstagerne på tværs af de politiske skel (421-422). Endvidere beskrives det, hvordan danske beslutningstagere og soldater hele tiden har søgt at finde på nye veje frem i operationerne i Afghanistan og Irak, selv om billedet ofte har været et skridt frem og to tilbage.

Mere kritisk rettes lyset i grufulde beskrivelser mod nedværdigende behandling og tortur af fanger i forbindelse med krigene i Irak og Afghanistan, en behandling som Danmarks nærmeste allierede havde ansvaret for, men som Danmark næsten uundgåeligt blev fedtet ind $i$. Derfor kan det være fristende at konkludere, at Danmark står sig bedst ved at holde sig fra de militære midler, og det er også et af bogens implicitte og eksplicitte budskaber (fx s. 666-670 og 672-673).

Danmarks militære aktivisme bør dog vurderes i et længere og bredere perspektiv. Forfatterne er opmærksomme på de danske militære engagementer i 1990'erne (fx s. 6366), men bogen kæder først og 
fremmest Danmarks militære aktivisme sammen med Bush-regeringens 'krig mod terror' og Fogh-regeringens stærke og næsten kompromisløse opslutning bag denne (fx s. 6667, 76-77, 221-225, 666-670).

Men Danmarks militære aktivisme startede allerede kort efter Murens fald i 1989 med dansk deltagelse i krigen om Kuwait. Bidraget var militært beskedent (korvetten Olfert Fisher), men politisk betydningsfuldt, og det blev under skiftende regeringer til højre og venstre for midten fulgt op af danske militære bidrag i blandt andet Kroatien, Bosnien og Kosovo op gennem 1990'erne. Dansk forsvar deltog således tilbagevendende i kamphandlinger som led i den såkaldte aktive internationalisme: Forsvar af international fred og sikkerhed, herunder truede befolkningsgrupper, baseret på folkeretten og typisk med klart FN-mandat (dog ikke i Kosovo).

\section{Aktiv amerikanisme}

Med de militære bidrag i Afghanistan og særligt Irak blev der i det efterfølgende årti ganske rigtigt tale om en decideret krigsdeltagelse, som tilmed var mere omfattende, langstrakt og tabsgivende. Men det afgørende skifte fra og med 2001 var måske ikke så meget brugen af de militære midler som led i dansk udenrigspolitik, men mere de ændrede formål og det ændrede grundlag: Sat på spidsen en ændring fra deltagelse i humanitær intervention på basis af FN og folkeretten til en deltagelse i 'krigen mod terror' på basis af venskabet med USA og de dertilhørende frihedsværdier. Eller mere polemisk: Fra aktiv internationalisme til aktiv terrorbekæmpelse eller aktiv amerikanisme.

Dette kan naturligvis ikke siges uden forbehold. Krigen mod terror rummede også elementer af internationalisme, herunder humanitære og demokratiske ambitioner samt statsopbygning i både Afghanistan og Irak, og disse elementer var givetvis også vigtige for de partier, der stod bag de danske engagementer. Tilsvarende var samarbejdet med USA og opbakningen til det amerikanske lederskab fremtrædende elementer under 1990'ernes aktive internationalisme. Men der skete en tydelig ændring i stødretningen for den danske udenrigspolitik og den militære aktivismes placering heri efter 11. september.

Det fremgår også af bogen, fx i dækningen af den borgerlige regerings interne diskussioner af, hvorvidt en $\mathrm{FN}$-autorisering af angrebet på Irak i 2003 var nødvendig eller ønskelig (kapitel 4), og i de implicitte og eksplicitte opfordringer til at overveje en dansk tilbagevenden til en mere diplomatisk, humanitær og fredsbevarede aktivisme (fx s. 670673). Grundlaget for krigene i Afghanistan og især Irak bliver således diskuteret og behørigt problematiseret, men det afsluttende indtryk af 


\section{LITTERATUR}

bogen er alligevel, at det i højere grad er det militære instrument i sig selv end det bagvedliggende politiske formål, der sættes til debat.

Dansk militær aktivisme har efterhånden lange linjer i dansk udenrigspolitik, og grundlaget har i forskellige situationer være mere eller mindre overbevisende, i hvert fald folkeretligt, ligesom resultaterne. Militære midler kan være velvalgte eller det modsatte; det afhænger af situationen og grundlaget. Så det store spørgsmål er måske ikke, om det militære instrument skal være i værktøjskassen for dansk udenrigspolitik, men mere hvad stødretningen skal være for denne udenrigspolitik, og hvad militære midler eventuelt kan bidrage med i den konkrete situation.

\section{Irak-krigens tvivlsomme grundlag}

Irak-krigens grundlag har været genstand for analyser og debatter, lige siden det blev klart, at USA overvejede at føre krigen mod terror videre fra Afghanistan til Irak, selv om der i 2002 og 2003 ikke var indikationer på, at landet udgjorde nogen klar eller akut trussel mod den internationale fred og sikkerhed.

Bogen bidrager alligevel på dette punkt, ikke mindst i det centrale kapitel 4. Dels med et sammenhængende billede af den internationale situation, FN-resolutionerne og våbeninspektørernes arbejde, de amerikansk-britiske overvejelser og den danske beslutningsproces. Dels med et sæt centrale spørgsmål, som den danske offentlighed og de politiske beslutningstagere ikke kan komme uden om at se på igen:

Hvad betyder det for vurderingen af Irak-krigen, at beslutningen om at angribe var udgangspunktet, mens begrundelsen for krigen var en udfordring, som USA, Storbritannien og Danmark måtte løse bedst muligt? Hvad betyder det for vurderingen af krigen, at FN's våbeninspektion blev bragt til ophør af angrebet, netop som det så ud til, at inspektørerne var tæt på at frikende Irak for besiddelse af de påståede masseødelæggelsesvåben? Hvordan kan man fra dansk side hævde, at den danske deltagelse skete for FN's skyld, og for at sikre håndhævelsen af FN's resolutioner, når FN's generalsekretær Kofi Annan udtalte, at et angreb på Irak ikke ville være i overensstemmelse med FN-pagten? Hvad betyder det for vurderingen af krigen, at et overvældende flertal i FN's Sikkerhedsråd (nærmere bestemt 11 ud af 15 lande) signalerede, at de ikke ville stemme for den indirekte bemyndigelse af et angreb på Irak, som ledende medlemmer af koalitionen cirkulerede op til angrebet på Irak, for derefter at trække den tilbage igen?

Disse centrale spørgsmål (og flere til) rejser bogen på overbevisende måde, selv om de ikke er nye. Til gengæld går bogen ikke så langt som den kunne i kritikken af det of- 
ficielle danske beslutningsgrundlag. Beslutningsforslaget B-118 omtales ofte som lidt af en genistreg, eftersom det ikke baserer sig på de irakiske masseødelæggelsesvåben, som aldrig blev fundet. Dertil siger forfatterne korrekt, at masseødelæggelsesvåben spillede en central rolle $\mathrm{i}$ den danske regerings generelle argumentation. Men der er også flere store problemer ved beslutningsforslagets bærende argument om, at Danmark gik i krig for at håndhæve FN's resolutioner. Herunder at de pågældende resolutioner netop handlede om, at Irak ikke måtte besidde masseødelæggelsesvåben!

Pointen, og her er anmelderens formentlig sammenfaldende med bogens, er ikke, at Irak-krigens grundlag slet ikke kan diskuteres, for det kan det. Fx er spørgsmålet om, hvad demokratier stiller op med de værste diktaturer, en reel politisk diskussion værd. Men der kommer ikke noget godt ud af at dække et politisk-ideologisk krigsgrundlag ind under FN-resolutioner, FN-procedurer, FN-udtalelser og folkeretlige grundregler, som reelt taler imod krig frem for det modsatte.

\section{Libyen: Tilbage til 1990'erne?}

Bogens sidste kapitel før efterskriften handler om Libyen - 'den uventede krig'. Dækningen er i sig selv nuanceret og udmærket, men den giver ikke for alvor anledning til en genovervejelse af Danmarks militæ- re aktivisme eller de lange linjer i dansk udenrigspolitik siden Murens fald. Efterskriften formes i høj grad af engagementerne i Afghanistan og Irak, samt den skiftende internationale kontekst: Et presset USA, der er tilbageholdende med militære engagementer, og som vil fortsætte 'krigen mod terror' med mere højteknologiske midler, herunder droneangreb.

Konklusionen bliver derfor, at de store krige mod terror er ovre - det er formentlig både rigtigt og udmærket - og at dansk aktivisme må finde nye veje, selv om den nye regering foreløbig holder fast i den forriges ideal om aktivisme, herunder også militær aktivisme (s. 672-673).

At der må findes nye veje for dansk aktivisme er givetvis også rigtigt, men den humanitære intervention i Libyen, det arabiske forår og den internationale udvikling kan også støtte en argumentation om, at den danske udenrigspolitik på en række punkter slet og ret er på vej tilbage til 1990'erne: Udviklingsbistand, fredsbevarelse, humanitære interventioner, statsbygning, opbygning af internationale institutioner og en international retsorden vil være på både det internationale samfunds og Vestens dagsorden, og hermed også på den danske.

Visse ting, herunder militære interventioner, bliver sværere bl.a. grundet ikke-vestlige stormagters voksende krav om indflydelse og reel vetoret, men behovet for at en- 


\section{LITTERATUR}

gagere sig i det internationale samfund, herunder fra tid til anden med militære midler, forsvinder ikke. Der vil i sådanne tilfælde være udsigt til FN-mandat bag danske militære engagementer, både af nationale og internationale grunde. Men det vil ikke forhindre alle de andre udfordringer ved krigsførelse og militær magtanvendelse, som beskrives så udmærket i Et land $i$ krig.

Den mest fundamentale lære af denne bog, samt af godt 20 års dansk aktivisme, er for undertegnede ikke, at det militære instrument skal lægges på hylden, ej heller at krigens problemstillinger kan løses, selv om der kan handles på tidligere erfaringer, men at grundlaget $\mathrm{i}$ hvert fald skal være $\mathrm{i}$ orden og $\mathrm{i}$ overensstemmelse med basale internationale principper.

Tonny Brems Knudsen er lektor $i$ international politik ved Institut for Statskundskab, Aarhus Universitet. 